\title{
Analysis of foreign experience in implementing state policies to ensure energy supply to remote areas
}

\author{
Maxim Gubanov ${ }^{1}$, Dmitry Morkovkin ${ }^{1}$, Arthur Gibadullin ${ }^{2 *}$, Olesya Dontsova ${ }^{1}$, Olga Gavel $^{1}$, and Manuchehr Sadriddinov ${ }^{3}$ \\ ${ }^{1}$ Financial University under the Government of the Russian Federation, 49, Leningradsky avenue, Moscow, 125993, Russia \\ ${ }^{2}$ State University of Management, 99, Ryazan Avenue, Moscow, 109542, Russia \\ ${ }^{3}$ Tajik State Finance and Economics University, 64/14, Nakhimova Street, Dushanbe, 734067, Republic of Tajikistan
}

\begin{abstract}
The article discusses the problems of providing consumers of electric energy in the decentralized energy supply zone by the example of economically developed countries with territories at the level of the Arctic Circle. An increase in the share of renewable energy sources in the energy balance of many fears as the main direction of regional energy development is shown. The energy policy of most Scandinavian states has a pronounced focus towards the maximum use of renewable energy sources along with the implementation of measures to save energy and increase energy efficiency. The provision on the priority use in the countries of the Arctic region of locally available energy sources, which include all types of renewable sources, as well as local hydrocarbons, is justified in order to ensure independence from external fuel supplies.
\end{abstract}

\section{Introduction}

The problem of energy supply to the territories in the decentralized energy supply zone is relevant not only for many northern countries, but also the determining energy policy for many island states. For the purposes of this study, the most economically developed countries with territories at the Arctic Circle are of particular interest, which include the USA, Canada, Denmark, Norway, Sweden, Finland and Iceland.

\section{Materials and methods}

The purpose of this study is to analyze foreign experience in implementing the state energy policy to ensure the supply of energy to remote areas in the Arctic zone. To achieve this goal, the following tasks:

- To conduct a comprehensive analysis of the problems of energy supply in the territories in the decentralized energy supply zone of the countries of the Arctic region;

- To determine the role of the electric grid infrastructure, which allows using the potential of geothermal and hydropower to ensure the reliability of the functioning of energy systems.

The study used general scientific and specific methods of system analysis, the method of analogy and comparison, the method of expert assessments, which allowed the authors to solve the goal and objectives of the study.

\section{Results}

USA (Alaska). The centralized power system in the state provides power to major cities and the railroad. The power supply of most small towns is local in nature and is mainly provided through the use of diesel power plants. Fuel is delivered by air, sea and road. The main primary energy resource in the region is natural gas $(65 \%)$, water energy $(22 \%)$ and coal $(10 \%)$, while successful experience in implementing renewable energy projects, including wind and solar energy, whose total balance is about $2 \%$ The total installed capacity of renewable energy is about 60 MW.

An example of the successful integration of renewable energy sources is the hybrid energy supply system of Kodiak Island, which consists of a $33 \mathrm{MW}$ power plant, a $30 \mathrm{MW}$ power plant, a $5 \mathrm{MW}$ wind farm, and a $3 \mathrm{MW}$ energy storage system. This allows you to provide more than $90 \%$ of electricity generation based on renewable energy sources. In addition, projects have been implemented for the construction of wind-diesel complexes in the settlements of Kotzebue, Wales, Kasigluk and villages on the west coast. In addition, a regional wind farm in the city of Anchorage (17.6 MW) is connected to the regional power system.

A separate area is the development of solar energy in Alaska in relation to private power supply systems.

A separate area is the development of solar energy in Alaska in relation to private power supply systems.

One example of this type of installation is a system with a capacity of $16.8 \mathrm{MW}$, installed at the Bering Strait Corporate Corporation in Nome in 2008. Another example is a $6.7 \mathrm{MW}$ photovoltaic project to power a school in Galen. SES was installed in 2012 and showed its effectiveness; in 2015 its capacity was increased to 10 MW.

Depending on the availability of geographically accessible resources of the province, the regions prioritize

\footnotetext{
*Corresponding author: 11117899@mail.ru
} 
the use of renewable energy sources. For the Aleutian Islands, this is an increase in the efficiency of the use of diesel fuel, the use of flue gases for heating, insulation and energy efficiency in the residential sector, wind-diesel stations. For the Copper River region, this is an increase in the share of energy use of water, natural gas, wind and the sun. Inner Alaska sets energy efficiency in the construction of new buildings and the use of biomass as priority areas. The Northwest Arctic focuses on the use of wind and solar energy, as well as the energy of sewage facilities [1].

The main direction of regional energy development is to increase the share of renewable energy sources in the energy balance to $50 \%$ by 2025 and to reduce the dependence of isolated energy systems on the "northern delivery" of fuel. As a primary measure, energy efficiency programs are in place. An additional program is being implemented to support the use of renewable energy sources through grants and soft loans from the Alaska Renewable Energy Fund. The reduction in diesel costs through the implementation of these measures is about $\$$ 45 million per year.

The Green Bank concept provides a different model, pushing the government away from direct support for energy projects to the strategic and cost-effective use of public funds. This approach encourages a shift from oneoff subsidies and grants to market-based financial instruments. The Green Bank provides cheap, long-term financing for supporting renewable energy projects by attracting private investment [2].

Canada (Yukon, Northwest Territories, Nunavut). Energy supply for most of the northern territories of the country is carried out through the use of hydropower potential in conjunction with diesel power plants. On the territory of the Yukon, the share of hydroelectric power plants in the total balance is more than $65 \%$, in the NorthWestern territories it is about $30 \%$. The largest project is a hydropower plant in Whitehorse (Yukon) with a capacity of $40 \mathrm{MW}$. In addition, projects in the field of wind and solar energy are being implemented. In particular, a $60 \mathrm{MW}$ solar power plant was built in Fort Simpson. On the island of Ramee, a project was completed to build a wind-diesel complex with a hydrogen storage system comprising a wind turbine $(690$ $\mathrm{kW})$, a hydrogen fuel cell $(250 \mathrm{~kW})$ and diesel generator set $(3 * 925 \mathrm{~kW})$.

At the same time, out of 80 communities in 53 territories, exclusively diesel electric generators are used to generate electricity in locally isolated networks. Diesel dominates the territory because, in many cases, it is the only guaranteed source for reliable energy supply in remote communities and isolated mining areas. In recent years, there has been a practice of using LNG for energy supply of certain settlements in coastal regions, in particular, the city of Inuvik [3].

RES projects are financed as part of energy conservation and energy efficiency programs, as well as environmental programs to reduce greenhouse gas emissions into the atmosphere. The search for a rational energy balance and an increase in the share of renewable energy is one of the main areas of territorial development.
Denmark (Greenland). More than 50 thousand inhabitants of the island are located on a vast territory and live in small communities along the fjords of the west coast. Most of these communities have complex transport accessibility. By natural conditions, the energy supply to the Greenland communities is ensured by the functioning of local energy centers. Historically, energy supply on the island was provided by imported diesel fuel, and was the largest source of greenhouse gas emissions. The change in European energy policy and the dynamics of world prices for petroleum products provided motivation for the use of geographically accessible resources, which include melt water energy.

Currently, up to $70 \%$ of the region's demand for electricity is provided by the operation of 5 hydroelectric power stations with capacities from 1.2 to $30 \mathrm{MW}$, providing autonomous power supply to urban settlements. In addition, about 70 autonomous energy systems operate in the region, where imported petroleum products are used as the primary source.

The Greenland government plans to build another 5 hydropower plants by 2030 to bring their share in the total balance to $90 \%$ and a corresponding reduction in greenhouse gas emissions. In addition, individual projects of private power supply through the use of solar and wind energy are being implemented. An example is the project in the Igaliku community, which includes a $100 \mathrm{~kW}$ SES, a $20 \mathrm{~kW}$ wind farm and an energy storage system [4].

Norway. Most of the country's territory is covered by a centralized power supply network. The main source of electricity production is hydroelectric power plants with a capacity of $33.8 \mathrm{GW}$, the share of which in the balance is more than $95 \%$, the remainder is thermal coal-fired power plants and wind power plants, the total installed capacity of which already reaches $800 \mathrm{MW}$.

As autonomous energy supply projects, one can pay attention to the energy supply system of Utsira Island, where an experimental combined wind turbine unit with a capacity of $2 * 600 \mathrm{~kW}$ was installed.

In 2017, the final energy consumption in Norway amounted to $213 \mathrm{TW}^{*} \mathrm{~h}$. Production and transportation were the sectors that used the most energy in 2015 , followed by services and households. Other sectors, such as construction, agriculture and forestry, and fisheries, provided only a small share of energy consumption.

The main focus of Norway's energy policy is to support renewable energy technologies in private households and energy efficiency in the residential sector. Due to the implementation of this direction, the average energy consumption per capita in the household sector decreased from 7\% between 1990 and 2017. Various factors have helped reduce energy consumption in the household sector, including the introduction of more energy-efficient equipment, stricter building codes and the increased use of electric and heat pumps for heating homes.

Central heating is carried out with the priority use of various fuels. In 2017 , about $50 \%$ of central heating was generated from waste and about $20 \%$ from bioenergy. The use of bioenergy has increased over the past ten years, while the use of fossil fuels has decreased. Biofuel makes up the second largest share of energy used for heating in 
households. In 2017, biofuels consumed about 5.8 TW*h of energy. Most of this energy is in the form of firewood, but households also use pallets and biomass. Oil and gas accounted for about $5 \%$ of the production of district heating systems [5].

Sweden. The lack of hydrocarbon deposits in the country was a determining factor in the development of energy. The main share in the energy balance is occupied by nuclear power plants $(43 \%)$, hydroelectric power plants $(41 \%)$ and wind energy $(7 \%)$. The remainder is provided through the use of other types of renewable energy sources, thermal power plants and the import of electricity from neighboring countries. Electric grid infrastructure provides coverage of almost the entire territory of the country.

Swedish nuclear power needs large investments, which is necessary to ensure increased safety requirements. The government says it is necessary to meet these requirements by 2020 , otherwise nuclear reactors will be decommissioned. Decisions have already been taken to decommission four reactors by 2020, which will require an increase in the share of renewable energy in the energy balance.

Electricity consumption in 2013 amounted to $125 \mathrm{TW}$ * $\mathrm{h}$. The residential and service sectors used the most electricity, then the industrial sector. Petroleum products are the next largest energy carrier after electricity, and the total end use was $96 \mathrm{TW} * \mathrm{~h}$, which represents an ongoing decline in recent years. In Sweden, the use of petroleum products is almost exclusively in the transport sector.

For heating and hot water supply of residential buildings, the most common use of electrical energy. Consumption in 2015 amounted to about $15 \mathrm{TW} * \mathrm{~h}$. In addition, biomass is used, including firewood, wood chips, sawdust and pallets. The use of oil for heating continues to decline with the development of a heat pump system, which is especially effective for heating low-rise buildings. District heating is the most common form of energy used for heating apartment buildings, and in 2015 amounted to $23 \mathrm{TW} * \mathrm{~h}$. Electric heating was a little over $1 \mathrm{TW}^{*} \mathrm{~h}$, and the use of fuel oil was less than $0.2 \mathrm{TW} *$ h.

Central heating is also the most common form of energy used for heating and producing hot water in nonresidential premises. In 2013, district consumption was 18 TW $*$ h. Electricity was the second largest and amounted to $3.3 \mathrm{TW} * \mathrm{~h}$. The use of oil for heating and hot water also continues to decline in non-residential premises. The total use of oil during the year is equivalent to $0.5 \mathrm{TW} *$ h.

The main long-term goals of the country are to increase energy efficiency in energy-intensive sectors of the economy and utilities, as well as simulate the development of renewable energy. The main support tools are the introduction of carbon dioxide emissions fees, tax benefits for renewable energy sources and green certificates [6].

Finland. The country's energy balance is determined by nuclear energy $(28 \%)$, hydropower $(16 \%)$, coal $(13 \%)$, natural gas $(5 \%)$, peat $(5 \%)$, wood and other renewable energy sources $(10 \%)$. In 2017 , electricity production amounted to $65 \mathrm{TW}^{*} \mathrm{~h}$, and from this $33.2 \mathrm{TW} * \mathrm{~h}$ were produced at nuclear power plants, 22.5 $\mathrm{TW} * \mathrm{~h}$ at hydroelectric power stations, $14.4 \mathrm{TW} * \mathrm{~h}$ at coal and gas power plants, and 16 at biomass, $8 \mathrm{TW} * \mathrm{~h}$. Taking into account imports of $23.9 \mathrm{TW} * \mathrm{~h}$, the total electricity consumption was $85.5 \mathrm{TW} * \mathrm{~h}$.

With its rich forest resources, Finland is a world leader in the development of biofuel. Forest industry by-products and wood waste are used as fuel for generating electricity and heat or are processed into second-generation biofuel, especially biodiesel, where Finnish industry leads the world. Since 2007, the supply of biofuel and waste has increased by $30 \%$, while the supply of oil has fallen by $9 \%$, while the supply of coal, natural gas and peat has decreased by almost $50 \%$. The global demand for Finnish forest products is growing, and as a result, the supply of these wood-based energy sources is also growing.

The government has set strategic climate goals for 2030 with an increase in the share of renewable energy in the energy balance to $40 \%$. A key goal in promoting renewable energy is to reduce greenhouse gas and waste emissions. Finland is a leader among countries in public and private spending on research, development and implementation of renewable energy projects. The longterm political framework for 2050 will be critical in guiding investment in clean energy technology innovation, which is a critical factor in achieving the goals of decarburization.

Finland's priority is energy efficiency, including utilities, the public sector, industry, energy and transport. The national energy efficiency program includes the following main areas: conducting an energy audit, developing energy conservation programs, using secondary energy resources and renewable energy sources, changing tax policies, conducting comprehensive research and implementing demonstration projects.

As one of the projects, it is worth bringing the integrated energy supply system of the city of Uusikaupunki, combining the use of waste, growing in greenhouses, fish farming and the production of biodiesel. In this closed-loop system, waste, energy and nutrients are recycled to minimize the total use of materials and emissions [7].

Iceland. The country's electricity needs are almost completely met through the use of renewable energy sources, including hydroelectric power plants $(12.8 \mathrm{GW} *$ $\mathrm{h}$ or $71 \%)$ and geothermal thermal power plants $(5.2 \mathrm{GW}$ $* \mathrm{~h}$ or $29 \%$ ). Wind energy and the use of hydrocarbons (less than 1\%) have an insignificant share. The installed capacity of geothermal stations is $665 \mathrm{MW}$ (the largest $300 \mathrm{MW}$ ), hydroelectric power stations - $1880 \mathrm{MW}$ (the largest $690 \mathrm{MW}$ ).

Electric grids cover the area around the entire island and provide transport of electricity from large sources of generation. $220 \mathrm{kV}$ power lines connect all the major plants serving the southwestern part of Iceland with the municipal district of Reykjavik and surrounding cities in the eastern part of Iceland. The largest hydropower plant is associated with the largest aluminum smelter in Fjardal.

The $132 \mathrm{kV}$ energy ring is used for transmission throughout the country and ensures the operability of the transmission network in post-accident conditions. 
The main consumer of electricity is aluminum industry $(68 \%)$, silicon industry $(8.7 \%)$, services $(5.7 \%)$, household services $(4.6 \%)$, utilities $(4 \%)$, agriculture $(1$, $2 \%$ ). Heat supply for more than $90 \%$ of houses is provided through the use of geothermal energy sources.

The main goal of state policy is to achieve carbon neutrality, which implies the complete exclusion of the use of fossil fuels through the use of renewable energy and increase the energy efficiency of economic sectors.

The main goals for the long term are: the diversification of industry with an emphasis on environmentally friendly technologies, the development of industrial parks and plants for the production of technological equipment for renewable energy sources, the development of centralized and individual heat supply through the use of geothermal energy sources, and the replacement of petroleum products in transport for environmentally friendly fuel [8].

\section{Conclusions}

Based on the analysis, it should be concluded that the countries of the Arctic region use priority sources of locally available energy sources, which include all types of renewable sources, as well as local hydrocarbons, in order to ensure independence from external fuel supplies.

The energy policy of the Scandinavian countries has an obvious direction towards the maximum use of renewable energy in conjunction with the implementation of measures to save energy and increase energy efficiency, which corresponds to the pan-European trend for the implementation of the "energy transition". A significant role is played by the developed electric grid infrastructure, which makes it possible to maximize the potential of geothermal and hydropower to ensure the reliability of the functioning of energy systems [10-21]. The North American countries and Denmark (Greenland) are seeking a rational balance between the development of electric grid infrastructure in extended territories and the use of local renewable energy sources to replace imported fuel.

\section{References}

1. Energy for a Sustainable Alaska. The Rural Conundrum. A commonwealth north study report, Meera Kohler \& Ethan Schutt, Co-Chairs, URL: https://www.denali.gov

2. Energy supply of isolated territories in Russia and the world, Analytical Center under the Government of the Russian Federation. Energy Bulletin, 2017, no 51, pp. 14-18.

3. Powering Canada's Territories, Standing Senate Committee on Energy, the Environment and Natural Resources, URL: https://sencanada.ca

4. Renewable energy across the Arctic: Greenland Report, WWF, URL: http://awsassets.wwfdk.panda.org/downloads/Greenl and_RE_Report_July_2017_v2.pdf
5. Energy facts Norway, Norwegian Ministry of Petroleum and Energy, URL: https://energifaktanorge.no

6. Energy in Sweden 2017, Swedish Energy Agency, URL: http://www.energimyndigheten.se.

7. Energy in Finland 2016, Statistics Finland, URL: http://www.stat.fi.

8. Energy statistics in Iceland 2017, National Energy Authority. Orkustofnun, URL: https://orkustofnun.is

9. J. Helliwell, R. Layard, J. Sachs, World Happiness Report 2018, New York: Sustainable Development Solutions Network, URL: https://s3.amazonaws.com/happinessreport/2018/WHR_web.pdf

10. Klaus Schwab, World Economic Forum, The Global Competitiveness Report 2018, URL: http://www3.weforum.org/docs/GCR2018/05FullRe port/TheGlobal CompetitivenessReport2018.pdf

11. Human Development Report 2016, United Nations Development Programmer, URL: http://hdr.undp.org/sites/default/files/2016_human_d evelopment_report.pdf

12. The Social Progress Index 2018, URL: https://www.socialprogress.org.

13. Gross domestic product 2017, World Development Indicators database, World Bank, URL: https://databank.banquemondiale.org/data/download /GDP_PPP.pdf

14. M.A. Eskindarova, N.M. Abdikeeva, The real sector of the economy in the context of the new industrial revolution: monograph, Moscow, Kogito-Center, 2019, 428 pp.

15. S A Tolkachev et al 2020 IOP Conf. Ser.: Earth Environ. Sci., 421, 032041

16. S.V. Bryukhovetskaya, K.A. Artamonova, A.A. Gibadullin, S.A. Ilminskaya, Z.M. Kurbonova, Management of digital technology development in the national economy, IOP Conference Series: Earth and Environmental Science, 2020, 421, 042018

17. I.N. Romanova, D.E. Morkovkin, V.N. Nezamaikin, A.A. Gibadullin, M.A. Ivanova, Formation of $a$ policy to ensure environmental safety in modern economic conditions, IOP Conference Series: Materials Science and Engineering, 2020, 734, 012166

18. A.A. Gibadullin, M.I. Sadriddinov, Z.M. Kurbonova, Yu.N. Shedko, V.V. Shamraeva, Assessment of factors ensuring sustainable development of the electric power industry in the context of transition to renewable energy sources of the national economy, IOP Conference Series: Earth and Environmental Science, 2020, 421, 032051

19. M.I. Sadriddinov, T.V. Mezina, D.E. Morkovkin, Ju.A. Romanova, A.A. Gibadullin, Assessment of technological development and economic sustainability of domestic industry in modern conditions, IOP Conference Series: Materials Science and Engineering, 2020, 734, 012051 
20. A.A. Gibadullin, V.N. Pulyaeva, E.N. Kharitonova, N.A. Kharitonova, Convergence of the Russian power industry in a period of declining reliability and sustainability of the industry, Journal of Physics: Conference Series, 2019, 1399, 033034

21. A.A. Yuryeva, M.I. Kuternin, A.A. Gibadullin, Ju.A. Romanova, Formation of mechanisms for the development of innovative activity in the industrial production of the Russian Federation, Journal of Physics: Conference Series, 2019, 1399, 033099 